\title{
Crop Production Challenges Faced by Farmers in Somalia: A Case Study of Afgoye District Farmers
}

\author{
Mohamed Ibrahim Abdi-Soojeede \\ Jobkey University, Mogadishu, Somalia \\ Email: drsoojeede@gmail.com
}

How to cite this paper: Abdi-Soojeede, M.I. (2018) Crop Production Challenges Faced by Farmers in Somalia: A Case Study of Afgoye District Farmers. Agricultural Sciences, 9, 1032-1046.

https://doi.org/10.4236/as.2018.98071

Received: July 8, 2018

Accepted: August 27, 2018

Published: August 30, 2018

Copyright $\odot 2018$ by author and Scientific Research Publishing Inc. This work is licensed under the Creative Commons Attribution International License (CC BY 4.0).

http://creativecommons.org/licenses/by/4.0/

\begin{abstract}
The objective of this article was to investigate existing challenges of crop production on farmers in Afgoye District lower Shabelle Somalia. The Focus was farmer's attitude toward existing or not constraints to their crop production and what the experts have seen and what are far from their perception. Sixty famers and academic experts were distributed questionnaires and interview about the constraints of crop production other than agricultural disciplines. This paper used survey descriptive research which facilitates easily connection between past constrains and challenges of crop production. Questionnaire was comprised in the following two parts; Part one; demographic variables and Part two; objective related questions. The study found both major and minor constraints are exists in the Somali farmers. The major constraints include unstable weather, water scarcity, pests damaging crops, and poor transportation, and minor constraints such as inability to access and use such as seed and fertilizers, lack of capital to buy, inadequate investment in irrigation which makes farmers very vulnerable to drought, and there is less knowledge and skill of all farmers. The finding with highest percentage that was challenged in Afgoye farmer was "there is fear of gunner and thieves in the farmers" and $75 \%$ of respondents strongly agreed and second question with highest score is "there is fear of conflict between rebels and government", and $61.7 \%$ of them selected strongly agreed.
\end{abstract}

\section{Keywords}

Crop Production, Challenges, Somali

\section{Introduction}

This Food insecurity is major issue in Somalia, which created hungry and fa- 
mine. Mostly in the years 2011/2012, 2015/2016 and 2017, there was devastating drought in Somali regions related with low rain fall, which impacted on severely rural communities and their cropping (farming system) and livestock production which destroyed total their livelihoods, also results death of livestock and out-migration of community itself.

Agriculture production is first income source and plays key role in Somali's economy. As we know before the civil war the Somali government exported hundreds of thousands of tons of crop and fruits production, but after the collapse of center government 1991, subsequently there was also falling down of Somali crop and fruits production position in the world market. Recent years there are stable in some regions. It seems somewhat sufficient for production requirement of local needs. Furthermore, the report of FOA 15 Dec. 2005, mentions that roughly $50 \%$ of Somalia population's cereal requirements are met through domestic production, because mostly they are agro-pastoralist, which means they mix livestock and crop production depending on place they reside in [1].

Somalia has faced a lot of challenges effecting livelihood including drought, so it evokes another effect which was difficult to mitigate (for example environmental degradation) but this effect can be preventable. McCalla, A. F Spring, 2001, USA, he speaks challenges to World Agriculture in the 21st Century. $\mathrm{He}$ found that not only drought is challenge but there are other challenges such as insecurity, environmental degradation, and lack of knowledge and skills etc.

The zone of most field farms was controlling by terrorist groups Al-Shabab. Most farmers feel fear for visiting and natural cultivating their farms according to insecurity. The main and threat challenge was drying out of rivers in the some seasons that can automatize loss of already and recent cultivated crops, and evoke the general low morality of farmers for second sowing, that can related low yield in that season.

The constraints that crop production faces can be categorized into security, social and culture, ecological/environmental degradation, farm tool availability and market and prices; so researcher critical require knowing the main common constrains that need to interfere before it creates hazard to the life.

This article contributes to discover the constrains of crop production and also provides direction to the agronomists to aware of that constrains in Somalia particular southern region to develop strategies that may positively influence the future challenges of crop production. Furthermore, the findings of this study may be used by Government, International Nongovernmental Organizations (INGOs), Local Nongovernmental Organizations (LNGOs) and Agronomists who are willing to conduct further researches in the area.

\section{Organization of the Paper}

In this article consist of seven sections. First Section is introduction, second Section literature review, methodology is third Section, result is fourth Section, fifth 
Section discussion and conclusion, sixth is acknowledgement and last seventh Section is reference.

\section{Literature Review}

The studies related to the challenges of crop production and farmers became one of the interested published issues in recent years. For example, McCalla, A. F. (2001) USA, he speaks challenges to World Agriculture in the 21st Century, he mentioned three main challenges including Global Food Security, Poverty Reduction and Sustainable Natural Resource Management. He concluded that feeding two billion more people will be an enormous challenge. The bottom line is that virtually all of the increase in production globally will have to come from knowledge-based agricultural intensification, using modern science and biological technology, accompanied by improved capacity to deal with biotic and abiotic stresses [2].

Somalia has been transformed form fail state to transitional government and into the federal government. The food insecurity still exists in the many Somali communities of the urban and rural residents. Somali Agro-Pastoralists have somewhat storage likes (cave) they put their cereals after harvested and little processed in to the caves and then covered known as Somali language (Bakaar). Unfortunately most rural Somali Agro-Pastoralists have fled into the large cities after they met extreme perpetual drought and famine, still they are in the Internal Displaced People (IDP) camps.

In another side there is no policy and regulation management which will reduce the very load export of many natural resource such wood, coal, and wildlife, those are greatly integral part of the soil and land resource sustainability.

Nnenna Obidike (2011) investigating Nigeria Nsukka local government area of Enugu State, with rural farmers' problems accessing agricultural information: he found rural farmers are not well-known to produce enough food, probably due to some constraints that lead to lack of access to timely and up-to-date information which would have enabled them to achieve optimal yield from their farmlands. It was also found lack of access to basic agricultural knowledge and information by rural farmers in Nsukka local government area of Enugu State which may be as a result of certain constraints has made these farmers to stick to their old traditional methods of farming system and animal husbandry practice [3]. Olukunle, T. (2013) examined Nigeria government challenges and prospects of agriculture. The identified constraints he found included marketing problem, infrastructure inadequacies, and unstable input and output prices [4]. In Somali the farmers who are resident on the rural and villages have not educated to their children reason of lack of school near to their area and lack of awareness of the importance of education, so we could guess that they also have not timely and updated crop production knowledge and information.

In Afgoye there are constrains such as less labor force and farm equipments the farmer still use obsolete technologies such as the hand-hoe. But there are 
some exceptional which use tractor with old version, with more expensive rented; working hours during first tillage. Kenga, $\mathrm{R}$ et al. they analyse constraints to agricultural production in the Sudan-Sahelian zone of Cameroon using a diagnostic survey. They found Large variations exist in agriculture management practices among villages and households in terms of access to resources, such as labors, fertilizers, livestock, farm equipment, and land [5].

Spiertz, H. (2013) examined challenges for crop production research and improving land use, so he found that most critical are water scarcity in regions that depend on stored water reserves (aquifers) and the looming shortage of phosphorus reserves. And he also found land availability for food has been considered over the last three decades to become scarce, in Somalia land wealthier than other business [6]. Makuvaro V. et al. (2017), Zimbabwe, they have been investigated crop production and adaptation strategies constraints in central and western Zimbabwe on small holder farmers, so they found sixty percent of the farmers in both communal areas experienced shortage of planting seed, while shortage of fertiliser was reported by $75 \%$ and $30 \%$ of the farmers in lower Gweru and Lupane, respectively. Labour was a major constraint to $65 \%$ and $20 \%$ of the farmers in both locations, respectively; while draft power shortage affected $50 \%$ and $25 \%$ of the farmers [7].

Matto, J. M. et al. in India they search topic constraints faced by the paddy growers in adoption of recommended paddy production practices in Budgam district of Kashmir, India. They found the major constraints faced by the farmers in adoption of recommended paddy production practices were lack of skill in seed treatment $(98.88 \%)$, lack of technical advice for seed storage $(93.33 \%)$, irregular visits of agricultural officers (94.44\%), low rate of paddy in local market (84.44\%), high cost of fertilizers $(82.22 \%)$, high rate of seeds $(72.73 \%)$ and inadequate and untimely supply of loans (80\%) [8].

In Somalia particular our geographical scope (FSNAU Somalia 2013) conducted study in lower Shabelle Riverine Zone. The FSNAU discussed factors affecting agricultural production, which were included two factors, Land tenure, ownership and access and irrigation infrastructure. So they mention after the collapse of central government, there was confusing and non-obvious land tenure system in lower Shabelle leading to constant conflicts, land-grabbing and even displacement. They also presented factors that led to the food security crisis and subsequent famine in lower Shabelle in 2011, they list in the following; very poor crop harvest (production shock), limited on farm employment opportunities (labour constraints), import bottlenecks (trade constraints) [9].

The main uncontrollable challenge is climate changes which now days increased its effect on the world in Afgoye nearly 4 times the Shabelle River was dry out, and rain was low more than five years. Devendra, C.; 2012, he was declared effects that can emerge when climate changes in agro-ecological zones (AEZs). His research was climate change threats and effects: challenges for agriculture and food security in Malaysia. He said "The climate change effects are 
serious and wide ranging, and cause inter alia reduced soil moisture, increased water stress and reduced yields from cropping systems; expansion of semi-arid and arid agro-ecological zones (AEZs); increased droughts; increased rangelands; increased woody encroachment; expanding desertification; increased heat stress on animals; overstocking of heat tolerant animals" [10].

The low rainfall and continues drought occurrence causes less developed crop production methods, some farmers used irrigation of shallow wells and deep wells which still not common the area, the reason is dependence of river, as mentioned role of rainfall in development, Ofana, G. O. et al. (2016) they study constraints to agricultural development in Nigeria, they found empirical findings reveal that rainfall, exchange rate and food export (lag one) are the most significant positive determinants of agricultural output in Nigeria [11].

Author names and affiliations are to be centered beneath the title and printed in times 12-point, non-boldface type. Multiple authors may be shown in a twoor three-column format, with their affiliations below their respective names. Affiliations are centered below each author name, italicized, not bold. Include e-mail addresses if possible. Follow the author information by two blank lines before main text.

\section{Methodology}

The main objective of this paper was to investigate existing challenges and constrains of crop production on Somali farmers particularly Afgoye district. The study used primary data (see Appendix) extracted from farmer, farm workers, renters and others (academic experts) living Afgoye district. Sample size was 60 persons out of 71 individuals with the use of the sample size calculating formula known as Slovene's Formula. Quantities research used a structured questionnaire developed by Matto, J. M. et al. (2017), some modifications has been made and added others to meet the objectives of the study and questionnaire usually contain closed-ended questions. Descriptive statistics for overall challenges were presented. To examine the Demographic variation of research, the researcher utilized a frequency distribution.

Study Area: Afgoye is located 30 kilometres west away from Mogadishu there are numerous villages in which under Afgoye. The district is part of lower Shabelle region in southwestern Somalia is a very beautiful city in a strategic location. The population is estimated at approximately 79,400 residents and also has livestock market in lower Shabelle. The town has a large area of farmland. The district has Shabelle River is the longest river in Somalia. The climate is normal and has four seasons, with two rainy seasons, winter and summer; the temperature is moderate. It compasses by Shebelle River it has agricultural fields that is suitable for cultivation of fruits, vegetables and cereals grain its export is not much more and most of the farmers are subsistent farmers where by the crops they grow are mostly home use. Researcher visited north side and south farmers which were mostly cultivated cereal crops such as Maize, Sorghum and Sesame, 
also the center of the district.

The research was started 1st April 2018; the data were distributed and collected five (5) days 1-5 June 2018; the data analysis methods were quantitative methods by using frequency and descriptive research with deeply explained mean score of each questions.

This survey research for discovering existed challenges in local farmers, was encouraged the administration of Jobkey University, data collectors were students of agriculture those gave training to distribute questionnaire and interviewing the respondents.

\section{Results}

This research endeavors to categories the result into demographic data and constraints; the constraints itself divided into major constraints and minor constraints faced by Somali farmers to crop production.

\subsection{Demographic Data}

Table 1 showed one category which was the demographic data of the respondents. The research sample was 60 persons comprise with farmers, farm workers, renters and others (academics). Majority of the respondents' age were in between $25 \%$ - 35, 51.7\%. And 30\% were in between 35 - 45 years old, $10 \%$ were in between 45 - 50 and the remaining $8.3 \%$ were more than 50 years old. Majority of sex group of the respondents were $80 \%$ of males and $20 \%$ of females. In addition, majority of the respondents (51.7\%) were married, while the other $38.3 \%$ were single and remaining $10 \%$ were divorced/window. This result illustrated that the majority of respondents were in marriage and between 25 to 35 years old.

Education level of the respondents, $40 \%$ was bachelor, 25\% were primary, while $23 \%$ was uneducated and the remaining $7 \%$ were secondary level. Furthermore ownership, the majority of respondents $38 \%$ were farm workers, $25 \%$ were farm owners, whereas $12 \%$ of the respondents were others (academic students), and the remaining $10 \%$ were renters. This result explains $40 \%$ of others (academic students) and some owners, workers and renters have bachelor. But the remaining were uneducated, primary and secondary level.

\subsection{Reliability of Data}

The reliability test of this research was carried out. This test measures the internal consistency of a set of scale items; this research used Cronbach's coefficient alpha, to indicate reliability of data, the Cronbach's coefficient alpha can take value between 0 and 1 . So the closer to 1 means the more reliable of the scale of our variable. It is shown in Table 2 the Cronbach's alpha was 0.865 .

\subsection{Main Constraints of Crop Production}

The results of Table 3 showed, 55\% most of respondents agreed and strongly agreed (28.3\% and $26.7 \%$ respectively) that climate problem in general unstable 
Table 1. Demographic data.

\begin{tabular}{|c|c|c|}
\hline \multicolumn{3}{|c|}{ Age of respondents } \\
\hline & Frequency & Percent \\
\hline $25-35$ & 31 & 51.7 \\
\hline $35-45$ & 18 & 30.0 \\
\hline $45-50$ & 6 & 10.0 \\
\hline More than 50 & 5 & 8.3 \\
\hline Total & 60 & 100.0 \\
\hline \multicolumn{3}{|c|}{ Sex of respondents } \\
\hline Male & 48 & 80.0 \\
\hline Female & 12 & 20.0 \\
\hline Total & 60 & 100.0 \\
\hline \multicolumn{3}{|c|}{ Marital status of respondents } \\
\hline Single & 23 & 38.3 \\
\hline Marriage & 31 & 51.7 \\
\hline Divorce/Widow & 6 & 10.0 \\
\hline Total & 60 & 100.0 \\
\hline \multicolumn{3}{|c|}{ Educational level of respondents } \\
\hline Uneducated & 14 & 23.3 \\
\hline Primary & 15 & 25.0 \\
\hline Secondary & 7 & 11.7 \\
\hline Bachelor & 24 & 40.0 \\
\hline Total & 60 & 100.0 \\
\hline \multicolumn{3}{|c|}{ Ownership of respondents } \\
\hline Owner & 15 & 25.0 \\
\hline Worker & 23 & 38.3 \\
\hline Renter & 10 & 16.7 \\
\hline Others & 12 & 20.0 \\
\hline Total & 60 & 100.0 \\
\hline
\end{tabular}

Table 2. Reliability statistics.

\section{Reliability Statistics}

Cronbach's Alpha

0.865
$\mathrm{N}$ of Items

17 
Table 3. Main constraints of crop production.

\begin{tabular}{|c|c|c|c|}
\hline \multicolumn{4}{|l|}{ Descriptive statistics } \\
\hline & $\mathrm{N}$ & Mean & Std. Deviation \\
\hline Climate problem in general unstable weather & 60 & 3.52 & 1.269 \\
\hline Decreasing level of groundwater and river is serious problem & 60 & 3.70 & 1.499 \\
\hline Poor infrastructure, especially roads & 60 & 3.65 & 1.300 \\
\hline Crop damage by pests (insects, birds and pork) & 60 & 3.80 & 1.325 \\
\hline Problem relating land tenure, ownership of farm in community & 60 & 3.53 & 1.228 \\
\hline There is fear of conflict between rebels and government & 60 & 4.18 & 1.186 \\
\hline There is fear of gunner and thieves in the farmers & 60 & 4.28 & 1.354 \\
\hline Use of obsolete technologies such as the hand hoe & 60 & 3.62 & 1.223 \\
\hline Valid N (listwise) & 60 & & \\
\hline
\end{tabular}

weather are exists, with mean score 3.52 out of 5 . As well as the $60 \%$ of Respondents accepted (11.7\% greed and $48.3 \%$ strongly agreed) decreasing level of groundwater (shallow) and river is serious problem to crop production with mean score 3.70 out of 5 . Furthermore, $63.4 \%$ of the respondents were agreed and strongly agreed that there is poor infrastructure, especially roads with mean score 3.65 out 5. It suggested that crop damage by pests (insects, birds and pork) was common the Afgoye farms and $70 \%$ of the respondents agreed and strongly agreed (31.7\% and $38.3 \%$ respectively), the presence of pest with mean score 3.80 out of 5 .

With mean score 3.53 out of 5 , respondents answered that there problem relating land tenure, ownership of farm in community with $55 \%$ agreed and strongly agreed but $28 \%$ of the respondent answered neutral. As well as $60 \%$ of them strongly agree that there is fear of conflict between rebels and government, $10 \%$ agreed total $70 \%$ with mean score 4.18 out of 5 . But there is another fear of civil arm and thieves in farm area, $45 \%$ of respondents strongly agreed with mean score 4.28 out of 5 . The last is $53.4 \%$ of respondent agree and strongly agree $(21.7 \%$ and $31.7 \%$ respectively) farmers use of obsolete technologies such as the hand hoe with mean score mean 3.62 out of 5 .

\subsection{Less Constraints of Crop Production}

Table 4 presents the results less constrains of crop production; the result suggested $76.7 \%$ of respondent was agreed and strongly agreed that there is inability of farmer to access and use such as seed and fertilizers with mean score 4.00 out of 5. Moreover general there is also lack of capital to buy seed or fertilizers or other farm operations $71.6 \%$ agreed and strongly agreed (48.3 and 23.3 respectively), with mean score 3.68 out of 5 . In general $66.6 \%$ of the respondents agree and strongly agreed in same percentage (33.3\%) there is inadequate investment in irrigation which makes farmers very vulnerable to drought with mean score 
Table 4. Less constraints of crop production.

\begin{tabular}{llcc}
\hline \multicolumn{1}{c}{ Descriptive Statistics } & & & \\
\hline & $\mathrm{N}$ & Mean & $\begin{array}{c}\text { Std. } \\
\text { Deviation }\end{array}$ \\
\hline Inability of farmer to access and use such as seed and fertilizers & 60 & 4.00 & 1.207 \\
Lack of capital to buy seed or fertilizers or other farm operations & 60 & 3.68 & 1.214 \\
$\begin{array}{l}\text { Inadequate investment in irrigation which makes } \\
\text { farmers very vulnerable to drought }\end{array}$ & 60 & 3.65 & 1.388 \\
$\begin{array}{l}\text { High postharvest crop losses caused by } \\
\text { poor storage structures and inadequate access to pesticides }\end{array}$ & 60 & 3.53 & 1.228 \\
Inadequate market access for both crops and vegetable products & 60 & 3.48 & 1.396 \\
Unavailability of crop chemicals & 60 & 3.28 & 1.263 \\
There is less knowledge and skill of all farmers & 60 & 3.45 & 1.199 \\
Inadequate investment in processing of crop and other grains & 60 & 3.55 & 1.048 \\
Marketing process of crop is difficult and complex & 60 & 3.43 & 1.254 \\
Valid N (listwise) & 60 & & \\
\hline
\end{tabular}

3.65 out of 5. Furthermore, 53.3\% of respondents answered agree and strongly agree with same percentage (26.7\%), that there are high postharvest crop losses caused by poor storage structures and inadequate access to pesticides with mean score 3.53 out of 5 .

Inadequate market access for both crops and vegetable products, also exists and $53.3 \%$ of respondents accepted (agree and strongly agree) with mean score 3.48 out 5 . As well as $45 \%$ of them answered agree and strongly agree for unavailability of crop chemicals in the market with mean score 3.28 out of 5. Although there is less knowledge and skill of all farmers with $28.3 \%$ agreed while neutral and strongly agree presents same percentage (23.3\%) with mean score 3.45 out of 5 .

In addition $31.7 \%$ majority of respondents answered neutral, $30 \%$ agreed and $21.7 \%$ strongly agreed that there is inadequate investment in processing of crop and other grains with mean score 3.55 out of 5 . As well as $50 \%$ of respondents agreed and strongly agreed (in accordance with the scale of the study $25 \%$ and $25 \%$ respectively), the marketing process of crop is difficult and complex with mean score 3.43 out 5 .

\section{Discussion and Conclusion}

Challenges and constrains have bad effect in whole the production for a longtime. Since then, several researches have been conducted in various different countries-focusing on major and minor challenges facing on crop production. Therefore, this study aimed at examining challenges on crop production in Somali farmers at Afgoye district. The study found both major and minor constraints were existing in the Somali farmers; the major constraints include unst- 
able weather, water scarcity, pests damaging crops, poor transportation, problem relating land tenure, and ownership, fear of conflict between rebels and government and also there are some people who are looting crops when it harvested. The study also found minor constraints such as inability to access, use of seeds and fertilizers, and lack of capital for inadequate investment in irrigation which makes farmers very vulnerable to drought; there is less knowledge and skills for all farmers, such as, high postharvest crop losses caused by poor storage structures and inadequate access to pesticides, inadequate market access for both crops and vegetable products and unavailability of crop chemicals etc.

The importance of finding with highest percentage that was challenged in Afgoye farmer was "There is fear of gunner and thieves in the farmers" and $75 \%$ of respondents strongly agreed and second question with highest score is "There is fear of conflict between rebels and government", and $61.7 \%$ of them was selected strongly agreed. That is real fear and oral asked questions-what is primary challenge after natural disasters; mostly they said security. The other challenges facing farmer was decreasing level of groundwater and river is serious problem; inability of farmer to access and use such as seed and fertilizers and crop damage by pests (insects, birds and pork), and percentage $48.3 \%, 45 \%$ and $38.3 \%$ strongly agreed respectively.

This study uncovered some of challenges that exist in the local Afgoye district, as researcher liked to suggest some points to the farmers, agronomists and official government.

1) Must get first peace and security in local communities and prevention of conflicts and make negotiation to rebels.

2) Farmers must as a matter of necessity adopt local climate change, and must try to make strategies for the development all basic needs of the production.

3) Government must interfere farmers and make continuous research to improve their productivity and to correct their errors. Also government is responsible for rebuilding of roads and continues monitoring climate changes.

4) Government must be make strategies for reducing both constraints to crop production in Somali farmers at Afgoye and other related places.

The researchers that are willing to undertake further studies in this area are advised to investigate factors effecting soil towards the occurrence of drought and also to increase the target population of the study with more than one district.

\section{Acknowledgements}

First Researcher give thanks to Jobkey University administration, particular Rector Dr. Abdiaziz Agane, Deputy Prof. Abdusalam Malla, also sends grateful appreciation to friends specially Mr. Mowliid Ahmed Hassan and other colleagues, who participated for completeness of this article, and also specially appreciated to assistance dean of faculty of agricultural and veterinary Dr. Ayub Abdi Ali, and the students of agriculture. 


\section{Conflicts of Interest}

The authors declare no conflicts of interest regarding the publication of this paper.

\section{References}

[1] FAO (2005) FAO in Somalia, Agriculture: Building Resilience. http://www.fao.org/somalia/programmes-and-projects/agriculture/en/

[2] McCalla, A.F. (2001) Challenges to World Agriculture in the 21st Century; Agricultural and Resource Economics. Vol. 4, University of California, Davis.

[3] Obidike, N.A. (2011) Rural Farmers' Problems Accessing Agricultural Information: A Case Study of Nsukka Local Government Area of Enugu State, Nigeria. Library Philosophy and Practice, 660. http://digitalcommons.unl.edu/libphilprac/660/

[4] Olukunle, O.T. (2013) Challenges and Prospects of Agriculture in Nigeria: The Way Forward. Journal of Economics and Sustainable Development, 4, 37-45.

[5] Kenga, R., M'Biandoun, M., Njoya, A., Havard, M. and Vall, E. (2003) Analysis of Constraints to Agricultural Production in the Sudan-Sahelian Zone of Cameroon Uging a Diagnostic Survey. Savanes africaines. Des espaces en mutation, des acteurs face à de nouveaux défis, Garoua, 27-30 May 2002, 7.

[6] Spiertz, H. (2013) Challenges for Crop Production Research in Improving Land Use, Productivity and Sustainability. Sustainability, 5, 1632-1644.

https://doi.org/10.3390/su5041632

[7] Makuvaro, V., Walker, S., Munodawafa, A., Chagonda, I., Murewi, C. and Mubaya, C. (2017) Constraints to Crop Production and Adaptation Strategies of Smallholder Farmers in Semi-Arid Central and Western Zimbabwe. African Crop Science Journal, 25, 221-235. https://doi.org/10.4314/acsj.v25i2.7

[8] Matto, J.M., Dar, M.A., Shah, Z.A., Beigh, M.A. and Mir, R. (2017) Constraints Faced by the Paddy Growers in Adoption of Recommended Paddy Production Practices in Budgam District of Kashmir. International Journal of Current Microbiology and Applied Sciences, 6, 1206-1214. https://doi.org/10.20546/ijcmas.2017.612.137

[9] Food Security and Nutrition Analysis Unit (FSNAU Somalia) (2013) Subsistence Farming in Lower Shabelle Riverine Zone. United Nations Somalia, Nairobi.

[10] Devendra, C. (2012) Climate Change Threats and Effects: Challenges for Agriculture and Food Security. Academy of Sciences Malaysia, Kuala Lumpur.

[11] Ofana, G.O., Efefiom, E.C. and Omini, E.E. (2016) Constraints to Agricultural Development in Nigeria. International Journal of Development and Economic Sustainability, 4, 19-33. 


\section{Appendix: Frequency Tables (Percentage)}

Table A1. Climate problem in general unstable weather.

\begin{tabular}{cccccc}
\hline & & Frequency & Percent & Valid Percent & Cumulative Percent \\
\hline & Strongly Disagree & 6 & 10.0 & 10.0 & 10.0 \\
& Disagree & 6 & 10.0 & 10.0 & 20.0 \\
\multirow{3}{*}{ Valid } & Neutral & 15 & 25.0 & 25.0 & 45.0 \\
& Agree & 17 & 28.3 & 28.3 & 73.3 \\
& Strongly Agree & 16 & 26.7 & 26.7 & 100.0 \\
& Total & 60 & 100.0 & 100.0 & \\
\hline
\end{tabular}

Table A2. Decreasing level of groundwater and river is serious problem.

\begin{tabular}{cccccc}
\hline & & Frequency & Percent & Valid Percent & Cumulative Percent \\
\hline \multirow{4}{*}{ Strongly Disagree } & 8 & 13.3 & 13.3 & 13.3 \\
Valid & 7 & 11.7 & 11.7 & 25.0 \\
& Disagree & 9 & 15.0 & 15.0 & 40.0 \\
& Neutral & 7 & 11.7 & 11.7 & 51.7 \\
& Agree & 29 & 48.3 & 48.3 & 100.0 \\
\hline
\end{tabular}

Table A3. Poor infrastructure, especially roads.

\begin{tabular}{cccccc}
\hline & & Frequency & Percent & Valid Percent & Cumulative Percent \\
\hline \multirow{4}{*}{ Strongly Disagree } & 6 & 10.0 & 10.0 & 10.0 \\
& Disagree & 6 & 10.0 & 10.0 & 20.0 \\
& Neutral & 10 & 16.7 & 16.7 & 36.7 \\
& Agree & 19 & 31.7 & 31.7 & 68.3 \\
& Strongly Agree & 19 & 31.7 & 31.7 & 100.0 \\
& Total & 60 & 100.0 & 100.0 & \\
\hline
\end{tabular}

Table A4. Crop damage by pests (insects, birds and pork).

\begin{tabular}{|c|c|c|c|c|c|}
\hline & & Frequency & Percent & Valid Percent & Cumulative Percent \\
\hline \multirow{6}{*}{ Valid } & Strongly Disagree & 7 & 11.7 & 11.7 & 11.7 \\
\hline & Disagree & 3 & 5.0 & 5.0 & 16.7 \\
\hline & Neutral & 8 & 13.3 & 13.3 & 30.0 \\
\hline & Agree & 19 & 31.7 & 31.7 & 61.7 \\
\hline & Strongly Agree & 23 & 38.3 & 38.3 & 100.0 \\
\hline & Total & 60 & 100.0 & 100.0 & \\
\hline
\end{tabular}


Table A5. Problem relating land tenure, ownership of farm in community.

\begin{tabular}{cccccc}
\hline & & Frequency & Percent & Valid Percent & Cumulative Percent \\
\hline \multirow{4}{*}{ Valid } & Strongly Disagree & 6 & 10.0 & 10.0 & 10.0 \\
& Disagree & 4 & 6.7 & 6.7 & 16.7 \\
& Neutral & 17 & 28.3 & 28.3 & 45.0 \\
& Agree & 18 & 30.0 & 30.0 & 75.0 \\
& Strongly Agree & 15 & 25.0 & 25.0 & 100.0 \\
& Total & 60 & 100.0 & 100.0 & \\
\hline
\end{tabular}

Table A6. There is fear of conflict between repels and government.

\begin{tabular}{cccccc}
\hline & & Frequency & Percent & Valid Percent & Cumulative Percent \\
\hline & Strongly Disagree & 3 & 5.0 & 5.0 & 5.0 \\
& Disagree & 2 & 3.3 & 3.3 & 8.3 \\
Valid & Neutral & 13 & 21.7 & 21.7 & 30.0 \\
& Agree & 5 & 8.3 & 8.3 & 38.3 \\
& Strongly Agree & 37 & 61.7 & 61.7 & 100.0 \\
& Total & 60 & 100.0 & 100.0 & \\
\hline
\end{tabular}

Table A7. There is fear of gunner and thieves in the farms.

\begin{tabular}{cccccc}
\hline & & Frequency & Percent & Valid Percent & Cumulative Percent \\
\hline \multirow{4}{*}{ Strongly Disagree } & 6 & 10.0 & 10.0 & 10.0 \\
& Disagree & 2 & 3.3 & 3.3 & 13.3 \\
& Neutral & 6 & 10.0 & 10.0 & 23.3 \\
& Agree & 1 & 1.7 & 1.7 & 25.0 \\
& Strongly Agree & 45 & 75.0 & 75.0 & 100.0 \\
& Total & 60 & 100.0 & 100.0 & \\
\hline
\end{tabular}

Table A8. Use of obsolete technologies such as the hand hoe.

\begin{tabular}{cccccc}
\hline & & Frequency & Percent & Valid Percent & Cumulative Percent \\
\hline \multirow{4}{*}{ Strongly Disagree } & 4 & 6.7 & 6.7 & 6.7 \\
& Disagree & 6 & 10.0 & 10.0 & 16.7 \\
& Neutral & 18 & 30.0 & 30.0 & 46.7 \\
& Agree & 13 & 21.7 & 21.7 & 68.3 \\
& Strongly Agree & 19 & 31.7 & 31.7 & 100.0 \\
\hline
\end{tabular}

Table A9. Inability of farmer to access and use such as seed and fertilizers.

\begin{tabular}{cccccc}
\hline & & Frequency & Percent & Valid Percent & Cumulative Percent \\
\hline \multirow{4}{*}{ Valid } & Strongly Disagree & 3 & 5.0 & 5.0 & 5.0 \\
& Disagree & 7 & 11.7 & 11.7 & 16.7 \\
& Neutral & 4 & 6.7 & 6.7 & 23.3 \\
& Agree & 19 & 31.7 & 31.7 & 55.0 \\
& Strongly Agree & 27 & 45.0 & 45.0 & 100.0 \\
& Total & 60 & 100.0 & 100.0 & \\
\hline
\end{tabular}


Table A10. Lack of capital to buy seed or fertilizers or other farm operations.

\begin{tabular}{cccccc}
\hline & & Frequency & Percent & Valid Percent & Cumulative Percent \\
\hline & Strongly Disagree & 7 & 11.7 & 11.7 & 11.7 \\
& Disagree & 2 & 3.3 & 3.3 & 15.0 \\
\multirow{3}{*}{ Valid } & Neutral & 8 & 13.3 & 13.3 & 28.3 \\
& Agree & 29 & 48.3 & 48.3 & 76.7 \\
& Strongly Agree & 14 & 23.3 & 23.3 & 100.0 \\
& Total & 60 & 100.0 & 100.0 & \\
\hline
\end{tabular}

Table A11. Inadequate investment in irrigation which makes farmers very vulnerable to drought.

\begin{tabular}{cccccc}
\hline & & Frequency & Percent & Valid Percent & Cumulative Percent \\
\hline \multirow{4}{*}{ Strongly Disagree } & 9 & 15.0 & 15.0 & 15.0 \\
& Disagree & 3 & 5.0 & 5.0 & 20.0 \\
\cline { 3 - 4 } & Neutral & 8 & 13.3 & 13.3 & 33.3 \\
& Agree & 20 & 33.3 & 33.3 & 66.7 \\
& Strongly Disagree & 20 & 33.3 & 33.3 & 100.0 \\
\hline & Total & 60 & 100.0 & 100.0 & \\
\hline
\end{tabular}

Table A12. High postharvest crop losses caused by poor storage structures and inadequate access to pesticides.

\begin{tabular}{cccccc}
\hline & & Frequency & Percent & Valid Percent & Cumulative Percent \\
\hline \multirow{4}{*}{ Strongly Disagree } & 5 & 8.3 & 8.3 & 8.3 \\
\multirow{3}{*}{ Valid } & Disagree & 6 & 10.0 & 10.0 & 18.3 \\
& Neutral & 17 & 28.3 & 28.3 & 46.7 \\
& Agree & 16 & 26.7 & 26.7 & 73.3 \\
& Strongly Agree & 16 & 26.7 & 26.7 & 100.0 \\
& Total & 60 & 100.0 & 100.0 & \\
\hline
\end{tabular}

Table A13. Inadequate market access for both crops and livestock products.

\begin{tabular}{|c|c|c|c|c|c|}
\hline & & Frequency & Percent & Valid Percent & Cumulative Percent \\
\hline \multirow{6}{*}{ Valid } & Strongly Disagree & 9 & 15.0 & 15.0 & 15.0 \\
\hline & Disagree & 4 & 6.7 & 6.7 & 21.7 \\
\hline & Neutral & 15 & 25.0 & 25.0 & 46.7 \\
\hline & Agree & 13 & 21.7 & 21.7 & 68.3 \\
\hline & Strongly Agree & 19 & 31.7 & 31.7 & 100.0 \\
\hline & Total & 60 & 100.0 & 100.0 & \\
\hline
\end{tabular}


Table A14. Unavailability of crop chemicals.

\begin{tabular}{cccccc}
\hline & & Frequency & Percent & Valid Percent & Cumulative Percent \\
\hline & Strongly Disagree & 7 & 11.7 & 11.7 & 11.7 \\
\multirow{3}{*}{ Valid } & 8 & 13.3 & 13.3 & 25.0 \\
& Disagree & 18 & 30.0 & 30.0 & 55.0 \\
& neutral & 15 & 25.0 & 25.0 & 80.0 \\
& agree & 12 & 20.0 & 20.0 & 100.0 \\
\hline
\end{tabular}

Table A15. There is less knowledge and skill of all farmers.

\begin{tabular}{|c|c|c|c|c|c|}
\hline & & Frequency & Percent & Valid Percent & Cumulative Percent \\
\hline \multirow{6}{*}{ Valid } & Strongly Disagree & 3 & 5.0 & 5.0 & 5.0 \\
\hline & Disagree & 12 & 20.0 & 20.0 & 25.0 \\
\hline & Neutral & 14 & 23.3 & 23.3 & 48.3 \\
\hline & Agree & 17 & 28.3 & 28.3 & 76.7 \\
\hline & Strongly Agree & 14 & 23.3 & 23.3 & 100.0 \\
\hline & Total & 60 & 100.0 & 100.0 & \\
\hline
\end{tabular}

Table A16. Inadequate investment in processing of crop and livestock.

\begin{tabular}{|c|c|c|c|c|c|}
\hline & & Frequency & Percent & Valid Percent & Cumulative Percent \\
\hline \multirow{6}{*}{ Valid } & Strongly Disagree & 1 & 1.7 & 1.7 & 1.7 \\
\hline & Disagree & 9 & 15.0 & 15.0 & 16.7 \\
\hline & Neutral & 19 & 31.7 & 31.7 & 48.3 \\
\hline & Agree & 18 & 30.0 & 30.0 & 78.3 \\
\hline & Strongly Agree & 13 & 21.7 & 21.7 & 100.0 \\
\hline & Total & 60 & 100.0 & 100.0 & \\
\hline
\end{tabular}

Table A17. Marketing process of crop is difficult and complex.

\begin{tabular}{cccccc}
\hline & & Frequency & Percent & Valid Percent & Cumulative Percent \\
\hline \multirow{2}{*}{ Strongly Disagree } & 5 & 8.3 & 8.3 & 8.3 \\
Disagree & 9 & 15.0 & 15.0 & 23.3 \\
& Neutral & 16 & 26.7 & 26.7 & 50.0 \\
& Agree & 15 & 25.0 & 25.0 & 75.0 \\
& Strongly Agree & 15 & 25.0 & 25.0 & 100.0 \\
& Total & 60 & 100.0 & 100.0 & \\
\hline
\end{tabular}

